
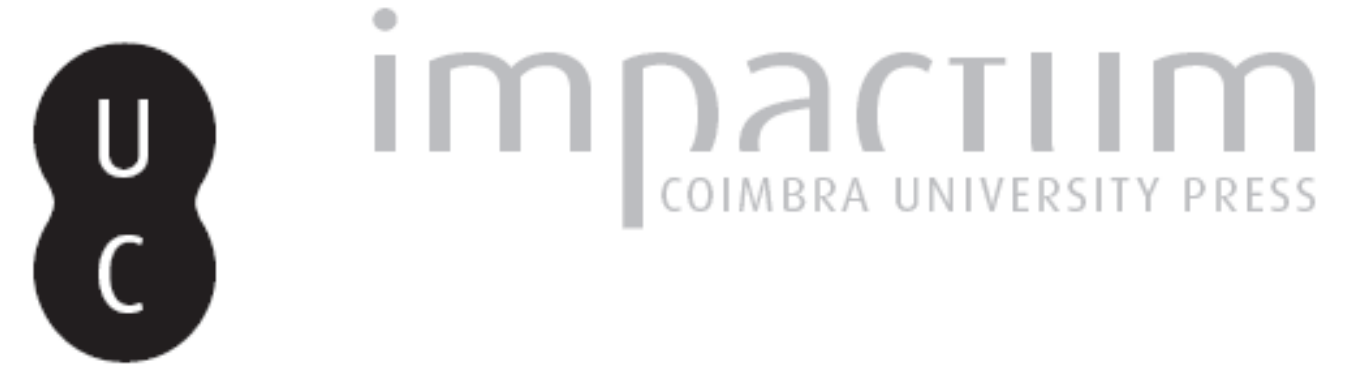

\title{
Ensaio de um programa de filosofia política
}

Autor(es): $\quad$ Pires, Edmundo Balsemão

Publicado por: Faculdade de Letras da Universidade de Coimbra, Instituto de Estudos

URL

persistente: Filosóficos

DOI: $\quad$ DOI:http://dx.doi.org/10.14195/0872-0851_36_3

Accessed : $\quad$ 26-Apr-2023 16:33:35

A navegação consulta e descarregamento dos títulos inseridos nas Bibliotecas Digitais UC Digitalis, UC Pombalina e UC Impactum, pressupõem a aceitação plena e sem reservas dos Termos e Condições de Uso destas Bibliotecas Digitais, disponíveis em https://digitalis.uc.pt/pt-pt/termos.

Conforme exposto nos referidos Termos e Condições de Uso, o descarregamento de títulos de acesso restrito requer uma licença válida de autorização devendo o utilizador aceder ao(s) documento(s) a partir de um endereço de IP da instituição detentora da supramencionada licença.

Ao utilizador é apenas permitido o descarregamento para uso pessoal, pelo que o emprego do(s) título(s) descarregado(s) para outro fim, designadamente comercial, carece de autorização do respetivo autor ou editor da obra.

Na medida em que todas as obras da UC Digitalis se encontram protegidas pelo Código do Direito de Autor e Direitos Conexos e demais legislação aplicável, toda a cópia, parcial ou total, deste documento, nos casos em que é legalmente admitida, deverá conter ou fazer-se acompanhar por este aviso.

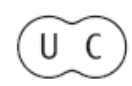




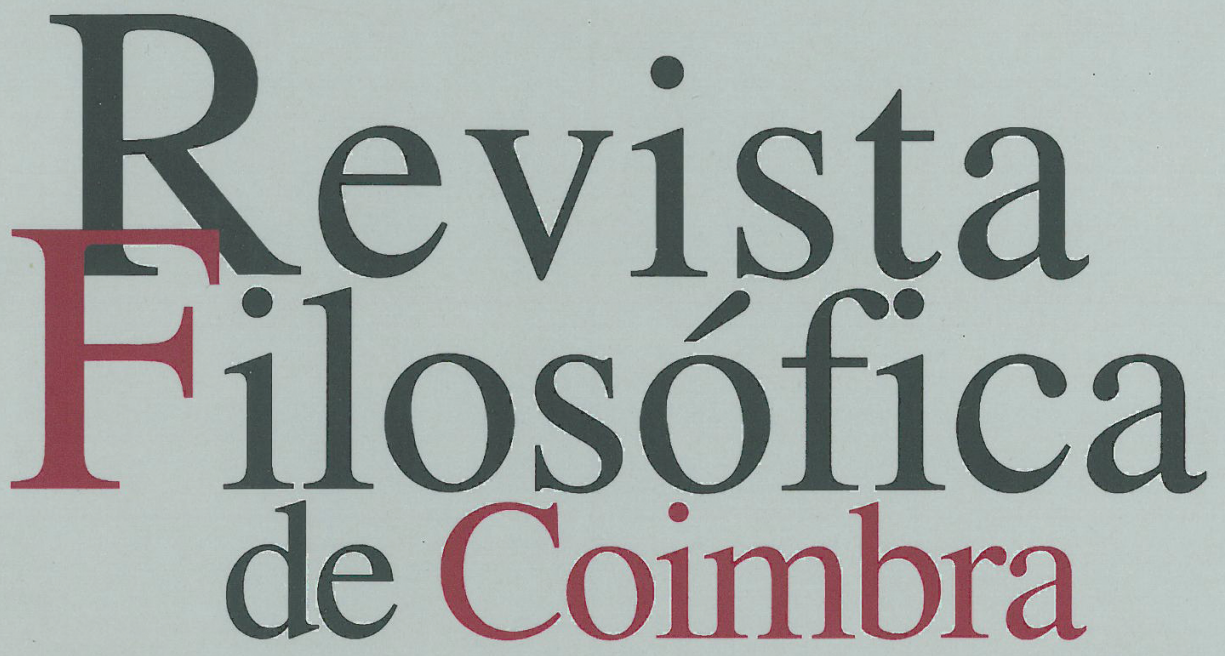

vol.19|n.036 | 2009

Henrique Jales Ribeiro Mario Santiago de Carvalho Edmundo Balsemão Pires Miquel Beltrán Ivo Oliveira 


\title{
ENSAIO DE UM PROGRAMA DE FILOSOFIA POLÍTICA
}

\author{
EDMUNDO BALSEMÃO PIRES*
}

Sumário: Este estudo procura esclarecer aspectos centrais das mutações do significado da Filosofia Política na modernidade. Para isso vai partir da caracterização genérica do tipo de discurso da ético-política do mundo antigo para evidenciar os nexos internos que mantém entre orientações descritivas e normativas do saber. Procura-se mostrar como a unidade ético-política clássica sofre alterações na medida em que se reconhece a diferença entre a história da consciência e a história da comunicação. Seguidamente, o trabalho procura clarificar, na modernidade, a relação entre a acção dos intelectuais, a construção de imagens políticas e as novas tarefas da Filosofia Política.

Palavras-chave: Modernidade, História dos intelectuais, Política, Filosofia Política.

Summary: This study seeks to clarify key aspects of the transformation of the idea of political philosophy in modern times. It starts from the general characterization of the Ethical discourse of the ancient world to highlight the link between the descriptive and the normative categories of practical knowledge. It aims to show how the classic ethical and political unity changes with the acknowledgement of the difference between the history of consciousness and the history of communication. Next, the paper seeks to clarify, in modernity, the relationship between the activity of the intellectuals, the construction of political images and the new tasks of political philosophy.

Keywords: Modernity, History of the intellectuals, Politics, Political philosophy.

\footnotetext{
* Departamento de "Filosofia, Comunicação e Informação" - F.L.U.C. - Universidade de Coimbra.
} 


\section{I - Os domínios de reflexão da Filosofia Política e a autonomia sistémica entre consciência e comunicação na sociedade moderna}

Uma certa prudência epistemológica louvável ditaria o princípio segundo o qual em matéria de Filosofia Política tudo se passa, hoje, no domínio da História Conceptual. Os grandes conceitos da Política filosófica seriam, todos sem excepção, noções herdadas de uma tradição que ninguém pode evitar. Esclarecer conceitos neste domínio significaria apropriar uma tradição e nela evidenciar um enredo terminológico, em que nós próprios nos situamos ${ }^{1}$. O saber filosófico-político seria uma variante reflexiva do saber histórico e impor-se-ia a análise do presente mediante o esclarecimento da efectividade histórica do passado.

Se a História Conceptual é mais que um apetrecho indispensável em qualquer investigação que ultrapasse os quadros mono-disciplinares e é tanto mais útil quanto sabemos que as chamadas "ciências humanas" não usam nem termos unívocos nem conceitos sem história já é mais discutível dizer que, para a Filosofia Política, é suficiente uma investigação de índole histórico-conceptual.

Tomarei a Filosofia Política como um saber cuja complexidade se deve ao duplo encapsulamento do discurso descritivo no discurso normativo. Deste ponto de vista não é adequada a sua redução ao pensamento histórico nem, no outro extremo, ao discurso normativo moral, legislativo ou a qualquer forma de preceptiva. Como saber de tipo composto a Filosofia Política goza dos privilégios da pendularidade do descritivo e do normativo e situa-se no plano da investigação histórico-terminológica (no quadro de uma investigação das persistências e das metamorfoses semânticas) mas também no âmbito de uma observação dos discursos normativos que a pode tornar relevante para a moral e para a legislação.

A Filosofia Política designa uma forma original de observação da sociedade moderna que só pode compreender-se mediante o esclarecimento de determinadas sobrevivências semânticas, de cuja tenacidade depende, em grande medida, a sua perseverança como disciplina e a nossa ocupação profissional. Como tipo especial de observação da sociedade moderna a Filosofia Política é sequela de uma determinada urdidura reflexiva, cuja complexidade importa não reduzir, antes importa seguir nos

${ }^{1}$ Embora o conceito e a proveniência da Begriffsgeschichte não seja totalmente uniforme e se possa falar, para além do sentido alemão da expressão, de um ramo de expressão inglesa, com "História Conceptual" quero referir-me, neste contexto particular, ao conjunto de trabalhos na linha de investigação que os Geschichtliche Grundbegriffe, editados por Otto Brunner, Werner Conze e Reinhart Koselleck, ajudaram a desenvolver na Alemanha.

${ }^{2}$ Cf. N. Luhmann, Gesellschaftsstruktur und Semantik I-IV, Frankfurt/M., 1993-1995. 
seus índices semânticos e terminológicos. Se a relação entre tradição terminológica e uso contemporâneo dos conceitos é forçosa deve também tornar-se objecto de escrutínio a relação entre uso da terminologia e "estrutura da sociedade". Este aspecto é um tema obrigatório na teoria dos sistemas, na obra de N. Luhmann, sob o título genérico "Estrutura da Sociedade e Semântica"2, em que me tenho inspirado em outros trabalhos tal como neste. A sua averiguação mais detalhada será decisiva numa teoria séria sobre a relação do sistema político, a sobrevivência conceptual e terminológica, a fórmula descritiva da "sociedade moderna" e a "Filosofia Política". Veremos como este enquadramento da "Filosofia Política" em articulação com outras formas de observação da sociedade moderna afecta o entendimento dos seus "objectos".

$\mathrm{Na}$ tradição do que identificamos com a Filosofia Política encontra-se uma modalidade de observação da sociedade e do sistema político que recorre à argumentação com vista a estabelecer critérios gerais de orientação normativa válidos numa comunidade ideal de agentes.

Neste modelo não só haveria lugar para as orientações normativas que caracterizam o discurso moral, como os aspectos de uma preceptiva política, as bases da legislação e, ainda, os aspectos mais gerais do discurso do Direito.

Na medida em que a Filosofia Política mantém da sua longa tradição os esquemas que, na sua origem histórica no pensamento grego, permitiam reconhecer a equivalência entre intenções, motivações e justificações para a conduta de agentes definidos e as aquisições mais estáveis, e menos vulneráveis a desapontamentos, da evolução institucional, a sua forma de observação deve poder rever-se na persistência e metamorfose da antiga unidade entre Ética e Política.

Não se pode apontar a equação para estabelecer as equivalências entre acção, evolução e estrutura da sociedade sem reduções num domínio que é, por excelência, o da complexidade. De facto, o grau de generalidade da terminologia e da argumentação com base na unidade ético-política reduz a diferença entre estruturas adquiridas pela evolução das sociedades, mais ou menos imunes ao poder dos argumentos voltados para a persuasão, e os sistemas psíquicos para os quais o poder da persuasão é mais evidente. No século XX, entre os teóricos da Filosofia Política, a ideia mais emblemática desta redução nunca explicitada da diferença do "psíquico" e do "social" encontra-se em Leo Strauss, na identificação de dois objectos intimamente associados na ético-política: o Homem e a Polis ${ }^{3}$.

Mesmo que fosse possível conceber uma orientação exclusivamente prática na Filosofia Política, simultaneamente argumentativa e preceptiva

${ }^{3}$ L. Strauss, What is Political Philosophy? And other Studies, Chicago / London, 1959 (reed. 1988); Idem, The City and Man, Chicago and London, 1964 (reed. 1978), p. 1 e ss.. 
e, portanto, orientada para a interacção, ela não poderia ser tomada isoladamente da relação entre semântica e estrutura da sociedade. Fazê- lo será cair na ingenuidade filosófica ou na escrita panfletária. Isto significa que se argumenta ou se recomenda esta ou aquela orientação prática a partir de arranjos semânticos e terminológicos disponíveis na forma da comunicação, no pressuposto da estrutura social, e não a partir daquilo que pretensamente o discurso normativo inventaria sem um fundo histórico. Se isto é certo, então não é exequível a separação entre as orientações normativas e as formas da observação da sociedade, o que de novo nos leva a não divorciar o plano descritivo do normativo. A conclusão a extrair é a de que a Filosofia Política não se reduz ao discurso prático.

Por outro lado, como aliás J. Habermas mostrou sistematicamente no seu ensaio de caracterização da força de mediação prática do modelo da "acção comunicativa", o conceito de acção relevante para as orientações normativas está ele próprio internamente seccionado e na avaliação que fez da diferença entre a Política clássica e a modernidade mostrou como os "modernos" vieram evidenciar o predomínio da acção estratégica face à orientação prudencial da concepção antiga do bem prático e da felicidade $^{4}$. Seguindo este diagnóstico, isso significa que, na modernidade, a conexão entre a acção e as orientações normativas não pode já ter como modelo exclusivo de referência do que é agir o tipo da deliberação racional da Ética aristotélica e a terminologia satélite - por exemplo, a procura da felicidade ou da utilidade própria.

Uma parte significativa da tradição moderna da Filosofia Política se apoiou na noção do cálculo racional da conduta de indivíduos que, estrategicamente envolvidos numa discriminação das opções mais adequadas para lhes garantir uma vida confortável e segura, se orientam para a escolha da melhor forma de "estado civil". A descrição da instituição do poder soberano que desde o século XVII o Direito Natural moderno consagrou na sua história ficcional da natureza e da associação humana, tendia a ligar a formação da sociedade civil aos efeitos de acções de agentes definidos, dando a ver um nexo interno entre fins das acções e instituição, criando assim a moldura imaginária para a observação da sociedade do homem comum. Das ideologias contratualistas dos séculos XVII e XVIII até ao utilitarismo, de J. Bentham a H. Sidgwick, e mesmo até certos aspectos do pensamento de J. Rawls e a algumas consequências do utilitarismo na teoria da sociedade de M. Weber e de T. Parsons, que este pressuposto de que a sociedade é feita por homens dotados desta ou daquela vontade, deste ou

${ }^{4}$ Cf. J. Habermas, Theorie und Praxis: sozialphilosophischen Studien, Frankfurt/M., 2000, 7. ${ }^{\mathrm{a}}$ ed, 1. Die Klassische Lehre von der Politik in ihrem Verhältnis zur Sozialphilosophie. 
daquele princípio determinativo do agir, decomponível em motivos racionais, está presente e serve para revelar uma determinada continuidade entre acção individual, estrutura da sociedade e as bases do sistema político ${ }^{5}$. É nesta presunção que assenta, igualmente, a proximidade, acima referida, entre os dois objectos da "Filosofia Política" segundo Leo Strauss.

No ensaio de fixação da especificidade da "Filosofia Política" a que este último filósofo se dedicou nas lições na Universidade Hebraica de Jerusalém, de 1954, evidenciava-se a diferença entre uma "solução clássica" e as "soluções modernas" do tema da articulação entre a motivação moral das acções humanas e a instituição política. Apoiado sobretudo nas Leis de Platão, o autor inseria na "solução clássica" a proposta de coordenação entre o que se entende como a "excelência humana" e o que é requerido colectivamente do "cidadão excelente" no conceito moral, antropológico e político de virtude do mesmo modo que na ideia sobre o "melhor regime para a cidade"6. L. Strauss fez assim ver como a exposição sobre o que é o "melhor regime para a cidade" constitui o objecto próprio da Filosofia Política clássica, mas na medida em que o "melhor regime" será não apenas o "melhor" à luz do que é necessário objectivamente garantir nas acções humanas mediante o papel regulador das leis civis para o governo da cidade, mas será também o "melhor" para a educação humana. Isto significa que o ideal antigo de Paideia atravessa os temas e a determinação do objecto da Filosofia Política clássica entre as determinações antropológicas da moral e as necessidades decorrentes da planificação da vida institucional da cidade nas principais magistraturas.

$\mathrm{Na}$ tradição da Filosofia Platónica o interesse educativo pelo "melhor regime" é evidente e relaciona-se, por um lado, com a doutrina da diferenciação em estratos da comunidade política e, por outro, com a distinção entre os tipos de doxa e a episteme e ainda, naqueles tipos, com a qualificação da opinião que deve conduzir os homens na acção prática.

Compreende-se, por conseguinte, que, no seu ideal, a Filosofia Política platónica esteja associada ao saber da realeza e que uma vertente dela fosse destinada a sistematizar e orientar a "opinião provável" do homem comum. A Filosofia Política constitui, assim, um modelo da referência

5 A forma decepcionante como Will Kymlicka na sua Introdução à Filosofia Política resolve o problema da distinção entre argumentação moral e Filosofia Política dá a ver o suficiente não tanto quanto à qualidade da obra deste autor mas sim quanto ao estado em que se encontra uma parte substancial da reflexão sobre estes temas na literatura recente de expressão inglesa. Cf. W. Kymlicka, Contemporary Political Philosophy. An Introduction, Oxford, 1990, especialmente pp. 1-8.

${ }^{6}$ L. Strauss, "What is Political Philosophy?" in Idem, What is Political Philosophy? And other Studies, op. cit., pp., 9-55. 
recíproca e cruzada dos pares do saber e da ignorância e do poder de agir e da impotência. Se reduzir um dos aspectos ao outro perde a unidade que lhe dá significado. Com base na reflexão destes aspectos, o seu discurso tem de estar adaptado às exigências da orientação prática mas também tem de responder aos requisitos de um saber do saber relativo às suas próprias condições e circunstâncias históricas.

Dos dados da formulação de L. Strauss é possível concluir que o berço clássico da Política, da ético-política, reside no ensaio de um acordo entre por um lado as determinações antropológicas da moral e as necessidades decorrentes da planificação da vida institucional da cidade e, por outro, dessa referência recíproca e cruzada dos pares do saber e da ignorância e do poder de agir e da impotência.

Explicitando e sistematizando, em redor da determinação do objecto da Filosofia Política clássica encontra-se um esquema tetrádico discursivo julgado apto para articular as bases antropológicas da conduta e a regulação da vida institucional; as relações entre formas de poder e tipos de saber.

O conceito de saber da ético-política clássica refere-se a uma organização das representações da consciência, do mesmo modo que o poder se refere a uma faculdade empírica de iniciar acções ou de se opor a acções alheias. $\mathrm{O}$ alcance da ligação entre poder e saber restringe-se aos limites da representação e à associação das representações para a consciência, o que cinge, igualmente, os limites da representação pela consciência da motivação, do tempo e da causalidade.

Do esquema de quatro pólos do discurso da Filosofia Política clássica se podem inferir dois temas modelares da tradição antiga e moderna da Política: o tema mais geral da virtude e o tema mais específico da justiça.

$\mathrm{Na}$ formação da modernidade, emblematicamente com Maquiavel e as doutrinas da "razão de estado", o esquema discursivo dos quatro pólos sofre uma mudança de tónica tendente a acentuar a polarização em redor da relação saber-poder, o que não implicará o desaparecimento da estrutura completa do esquema e dos temas associados.

As variações históricas no peso relativo dos quatro aspectos assentam, contudo, na convicção e na confiança, que tipifica o mundo clássico, na possibilidade de uma conversão recíproca dos motivos da estabilidade estrutural de sistemas e instituições em motivos justificativos da conduta de indivíduos dotados de projectos racionais de acção ou de vida e nas representações associadas. O modelo de justificação pela acção prática no seu núcleo motivacional e racional que encontramos no mundo antigo, no platonismo, em Aristóteles ou no Estóicismo, continuou a fascinar pela sua elegância, simplicidade e capacidade de mediação entre as dimensões comunicativas e os aspectos psíquicos (da representação) da temporalidade da acção, dos motivos e das consequências da conduta. 
Mas uma parte essencial da discussão do estatuto contemporâneo da Filosofia Política deve residir no significado da reconstrução das fontes da complexa estabilidade estrutural na linguagem da causalidade (motivação) das acções. Essa reconstrução tem limites históricos e semânticos não obstante o seu poder integrador. No caso da tomada de decisões política e no domínio da produção legislativa é forçoso que se constate o avanço irreversível da racionalidade burocrático-administrativa, consequência do predomínio do tipo de autoridade racional-legal, independente da capacidade para reduzir a causalidade da acção ao núcleo das representações conscientes, o que inviabiliza a tradução directa do motivo do decisor (ou legislador) em justificações aceitáveis imediatamente no núcleo motivacional da acção prática dos agentes e da sua representação da utilidade própria. A pretensão de converter todas as justificações válidas para o prolongamento da estabilidade estrutural de sistemas por via decisória e legislativa em motivos da acção prática de agentes conscientes de todos os elos de uma sequência causal pode conduzir ao cinismo, ao consenso forçado ou ao empolamento retórico da discussão pública das decisões por via parlamentar ou outra.

Na sociedade moderna, em redor da decisão política legal e burocraticamente estruturada e modulada e da sua justificação parlamentar se desenvolvem problemas que um teórico da Filosofia Política formado na tradição clássica da unidade ético-política, nas variações modernas das teorias da utilidade ou nas disposições descritivas da análise weberiana das acções terá dificuldade em compreender, na medida em que se encontra limitado por um conceito de saber e por uma ideia da relação entre saber-poder-acção limitado, à partida, pelo nexo das representações da consciência na sua relação com a causalidade do agir.

A forma da realidade social e política que é possível reter nas conexões das representações da consciência relativas à causalidade das acções é, ao mesmo tempo, limitada e muito geral. A sua generalidade deriva, aliás, da sua limitação. O Estado de Direito apropriou esta representação geral para enquadrar as bases do que a Constituição deveria garantir aos indivíduos no caixilho dos "direitos, liberdades e garantias" em sintonia com os valores das declarações dos "direitos humanos". Aqui, é de facto possível apreciar o liame entre a representação da causalidade das acções individuais, o sistema jurídico e o sistema político. Mas continuar a referir o mesmo nexo para esferas mais distantes da produção legislativa da ordem jurídica, para a decisão política em instâncias mais subordinadas ou, com outro sentido, para a decisão de agentes económicos é impraticável. Numa certa medida, é esta impossibilidade que, no caso da sociedade moderna, nos leva a pôr de lado a definição de sociedade como conjunto de todas as acções de agentes racionais. 
A mesma impossibilidade se conclui quanto às tentações no sentido de generalizar para a sociedade moderna, nas suas teias comunicativas de emergência incerta, o uso das noções clássicas de virtude e, particularmente, a de justiça. Importa, portanto, que se esclareça adequadamente de que se fala quando se aplica o conceito de justiça à configuração de políticas públicas do Estado moderno, como aliás acontece por exemplo com J. Rawls quando, em Uma Teoria da Justiça, procede à recuperação do tema da justiça distributiva da tradição clássica, como extensão do ético no político e como centro da avaliação das bases das políticas públicas redistributivas do Estado Providência, consciente de que se trata de um modelo justificativo de normas fundadoras do Direito Público ou da "estrutura social de base" dificilmente extensível, indiscriminadamente, a todas as fontes de legislação já atravessadas pelas exigências burocrático-administrativas. Para poder assegurar um significado institucional ao conceito de justiça J. Rawls atribuiu-lhe mais que um fundamento moral e reconheceu a importância da sua conversão em princípio processual da justificação de decisões e políticas públicas voltadas para a alocação equitativa de oportunidades, riqueza e condições objectivas da auto-estima.

$\mathrm{O}$ equilíbrio difícil entre a componente descritiva e a normativa da unidade ético-política reflecte-se também na avaliação que se fez do positivismo, do historicismo, da orientação descritiva para os "factos" e da distinção entre Filosofia Política e Ciência Política nas lições de Leo Strauss. No séc. XX, a discussão em redor do "positivismo" deu-nos provas concludentes.

A complexidade destas discriminações e em especial a importância da diferença entre esquemas da percepção (da consciência) e esquemas comunicativos na orientação normativa e descritiva da ético-política deve reter-se.

Assumindo este cuidado retomo agora cinco níveis essenciais de reflexão em redor da Filosofia Política.

1. Graças à interdependência forçosa entre temas fundamentais do pensamento político europeu e a História da Filosofia a Filosofia Política tem como um dos seus limiares de reflexão a própria História da Filosofia, pelo que a Filosofia Política reflecte categorias do pensamento filosófico da tradição na modalidade de pressuposições e, em certo grau, na forma de pressuposições não totalmente questionadas. Está neste grupo de pressuposições não analisadas o conceito de um mundo social dotado de uma "ordem" e de sujeitos racionais da conduta, por exemplo.

2. O que chamamos Filosofia Política articula-se também com a História Geral, aqui entendendo a História Política e as diferentes fontes da historicidade da cultura. Daqui se pode inferir o interesse 
cultural da Filosofia Política e a associação entre esta última e as orientações normativas presentes nos discursos públicos. Por outro lado, por meio da História Conceptual podem rever-se dimensões muito relevantes dos múltiplos cruzamentos entre Filosofia Política, semântica, tradição conceptual e estrutura da sociedade.

3. A Filosofia Política está reflexivamente associada com o que aqui designo por aspectos problemático-empíricos, ou seja, ela articula-se com aqueles temas que aparecem na dependência do mundo vivido mais imediato, em que se dá a experiência política e em que esta se incorpora em programas políticos e debates, nos quais se reflectem as intenções de uma condução instrumental de projectos políticos de agentes políticos e ainda questões de ordem moral mais geral. No contorno problemático-empírico o recurso à Filosofia Política é, na maior parte dos casos, um expediente para integrar topoi argumentativos. A ideia da Filosofia Política como uma fonte tópico-argumentativa representa, na maioria dos casos, um empobrecimento, uma restrição da própria complexidade interna dos temas filosóficos da política em virtude das necessidades instrumentais da retórica.

4. Para além disso, nos problemas de natureza epistemológica exprimem-se sempre elementos conceptuais e da semântica do discurso filosófico que se cruzam com problemas que os cientistas das "ciências sociais" continuam a investigar. Neste sentido muito específico é natural que o estudioso de Filosofia Política se defronte com a terminologia filosófica importada pelas ciências a partir da Filosofia, sendo certo que a maior parte das grandes categorias que as "ciências sociais" mobilizam para explicar a "realidade social" e política são antigos vocábulos da Filosofia, quantas vezes profundamente impregnados de metafísica. Constitui um terreno muito fecundo da Filosofia Política aquele em que se procura situar os fenómenos de resistência terminológica e semântica nas ciências, implicando o relacionamento entre uma epistemologia das "ciências sociais", a Filosofia Política e a História Conceptual. Uma "teoria da sociedade" ciente da sua própria herança semântica, como aquela que N. Luhmann praticou, tem de discutir permanentemente a validade dos seus conceitos e precisamente pelo facto de a "semântica da Velha Europa" estar em processo de constante deformação à luz das novas necessidades conceptuais ${ }^{7}$.

7 N. Luhmann, Die Gesellschaft der Gesellschaft, Frankfurt / M., 1997, Vol. 2, cap. 5, pp. 866-1150, especialmente pp. 893-958. 
5. A chamada dimensão crítica da actividade filosófica está presente, naturalmente, na Filosofia Política, no que consideramos ser a sua "tradição". Mas o próprio conceito de "crítica" se vai tornar uma noção a exigir escrutínio. É por isso que a crítica social e política não é a tarefa central da Filosofia Política, pois caso assim fosse a dimensão da inteligibilidade escapar-lhe-ia e tudo se poderia sacrificar à mais directa finalidade prática. Mais ainda, pelo facto de não poder desvincular-se a noção de "crítica" do discurso moral, a crítica não consegue, apenas por si mesma, subtrair-se à cristalização cultural das suas bases morais ${ }^{8}$. A Filosofia Política deve, pois, evitar assumir-se como discurso crítico, porque a Filosofia Política tem de se conservar uma actividade meta-moral, uma observação de segundo grau da moral. É neste último aspecto que a Filosofia Política tem mantido com os "intelectuais", como sujeitos e intérpretes do discurso moderno da "crítica", uma relação simultaneamente de proximidade e de distância. Caberia aqui explorar os nexos entre uma História dos Intelectuais, a semântica da ideia de "crítica" e as fontes das semânticas redutivas na relação com a argumentação ético-política.

Ao reescrever a tradição sociológica na teoria dos sistemas $\mathrm{N}$. Luhmann considerou que só a comunicação pode servir de base ao que designamos por sistemas sociais, entendendo por comunicação toda a "selectividade coordenada" do sentido, que ocorre mediante as três selecções da informação, da transmissão e da compreensão $o^{9}$. Com isto se cumpre uma parte do trajecto da história do pensamento sociológico no desenho da sua autonomia em relação à Psicologia, mas também se afirma uma tese que só na sociedade moderna pode ganhar toda a densidade: a tese da autonomia operatória das conexões psíquicas do sentido em relação às conexões comunicativas do sentido.

${ }^{8}$ Na reflexão filosófica e histórica o tema da relação entre "crítica" e discurso moral foi objecto de escrutínio rigoroso desde Hegel. O exame da "visão moral do mundo" é pelo filosofo empreendido já na Fenomenologia do Espírito e, depois da época de Jena, na parte dos Fundamentos da Filosofia do Direito dedicada à "Moralidade". Mais recentemente R. Koselleck estabeleceu os laços internos entre moral e crítica na sua célebre investigação sobre "Crítica e Crise". Cf. R. Koselleck, Kritik und Krise. Eine Studie zur Pathogenese der bürgerlichen Welt, Freiburg / München 1959 (reed. em Frankfurt / M., 1973). Para uma abordagem histórica do século XIX francês mas com referências a R. Koselleck e ao seu conceito da articulação entre crítica e moral cf. M. Riot-Sarcey, Le Réel de l'Utopie- Essai sur le Politique au XIX e. siècle, Paris, 1998, pp. 83 e ss, especialmente p. 100.

9 Cf. N. Luhmann, Soziale Systeme, Frankfurt / M., 1984, cap. 4, pp. 191-241, especialmente p. 195-198. 
Em outro trabalho tive já oportunidade de explorar alguns temas relacionados com esta tese da autonomia relativa da comunicação frente à consciência, em redor das noções de esquemas da percepção e esquemas da comunicação ${ }^{10}$. Uma parte das questões que se colocam aqui refere-se à diferença entre a temporalidade psíquica e a temporalidade da comunicação, que ilustra a impermeabilização relativa do que se desenrola na consciência frente ao que se desenvolve na comunicação.

A diferença entre comunicação e consciência pode ser lida do lado da comunicação ou do lado da consciência. Mas não há um conjunto destes dois conjuntos nem a forma de uma coincide com a forma da outra. É este aspecto particular e naturalmente as suas consequências teóricas que se deve tornar objecto da atenção dos filósofos da política, especialmente no que concerne à unidade ético-política que mais atrás caracterizámos nas suas linhas gerais.

N. Luhmann tentou traduzir as suas ideias sobre a impossibilidade de uma comunicação directa entre consciências ou entre "homens". Contra a noção de que os "homens" comunicam entre si, defendeu o sociólogo a ideia de que a "comunicação comunica". Mas este postulado, de que a sociologia contemporânea de inspiração luhmanniana extraiu consequências fecundas, tem a sua razão de ser numa determinada descrição da modernidade segundo a qual na "sociedade moderna" deixou de ser possível contar apenas com observações da "realidade social" tendo por fonte sistemas psíquicos, quer dizer, actos de consciência com determinados correlatos "objectivos".

É uma convenção do sistema de comunicação que é a sociedade, quando se parte da ideia de que os homens podem comunicar. Mesmo analistas dotados de grande agudeza foram induzidos em erro por esta convenção. (...) Mas os homens não podem comunicar, nem uma única vez os seus cérebros podem comunicar, nem uma única vez a consciência pode comunicar. Só a comunicação pode comunicar ${ }^{11}$.

A ideia segundo a qual a consciência influencia a comunicação ou pode estar presente nela é uma noção que apenas tem importância e apenas pode ser tornada inteligível por um observador que se encontrar em condições para estabelecer um nexo causal entre consciência e

${ }^{10}$ Cf. E. Balsemão Pires, „“Culture and Interpenetration: perception schemes and communicative schemes in the concept of Culture" in E. Balsemão Pires (org.), Espaços Públicos, Poder e Comunicação / Public Spaces, Power and Communication, Porto, 2007, pp. 139-156.

${ }^{11}$ Idem, "Wie ist Bewußtsein an Kommunikation beteiligt" in Idem, Aufsätze und Reden, Ditzingen, 2001, p. 111. 
comunicação. É a imputação causal por um observador que faz nascer a ideia de que os sistemas de comunicação operam como a consciência.

Ora, independentemente da verificação de determinados nexos causais entre os dois aspectos temos de partir da autonomia dos sistemas de comunicação frente à consciência. Isto não significa que a consciência e a comunicação nada tenham que ver uma com a outra. Impõe, antes, que o pensamento da associação entre as duas tenha de se reconhecer conceptualmente no terreno da observação. Toda a dificuldade adicional está ainda por vir quando nos defrontamos com o problema de saber se só a consciência observa a comunicação ou a "realidade social".

Nos fundamentos da Filosofia Política moderna está uma determinada concepção do sujeito. Mas, do ponto de vista do sujeito e de uma concepção da consciência assente no sujeito não é possível ir na direcção de outras consciências e de outros sujeitos diferentes do "ego". Esta impossibilidade está no âmago das doutrinas da "analogia", entre as quais se conta a doutrina fenomenológica da V Meditação Cartesiana mas também a tradição moderna da "simpatia" dos teóricos escoceses do séc. XVIII até Max Scheler. Sintomático é que nestas teorias que procuram o terreno da relação intersubjectiva se acabe por revelar, ao contrário, como é de facto impossível passar gradativamente da consciência do eu para as outras consciências pelo meio da comunicação.

N. Luhmann mostra como é impraticável a via que consiste em extrair a comunicação a partir da subjectividade e da consciência. $\mathrm{O}$ fracasso das teorias da analogia, que é possível constatar não apenas em E. Husserl como nas concepções fenomenológicas que partiram das evidentes dificuldades da V "Meditação Cartesiana" para empreender explicações alternativas, todas elas malogradas, levou o sociólogo a afirmar que a comunicação é uma esfera necessariamente autónoma que não se pode inferir de relações entre sistemas psíquicos particulares.

Mas se deste princípio é possível concluir directamente corolários para a concepção da acção e da interacção e daqui consequências relativas à possibilidade de subsistência das imagens da sociedade baseadas na unidade entre psiquismo e comunicação, é igualmente legítimo amplificar o seu alcance e questionar se não será certo que a própria diferença entre pessoas e coisas se organiza mediante a comunicação e não, exclusivamente, pela consciência ${ }^{12}$.

Destes seus pressupostos concluía N. Luhmann uma ideia dificilmente aceite por quem se recusar extrair e reflectir as consequências da distinção entre esquemas do processamento do sentido da consciência e esquemas

12 Idem, Ibid., p. 121. 
de processamento do sentido da comunicação: na Teoria Social o primado da teoria da linguagem assim como também o conceito de intersubjectividade deve, portanto, ser abandonado e no seu lugar surge o conceito de sistema fechado da comunicação social ${ }^{13}$.

É a este propósito que se justifica o recurso à autopoiésis. A auto-reprodução dos sistemas sociais baseia-se na capacidade de a comunicação continuar a comunicar mediante estruturas de conexões de comunicações autonomizadas na evolução e consolidadas segundo formas de racionalidade conectiva, para as quais a posição da consciência está sempre dependente daquilo que a comunicação determinar em cada caso. Com isto se relaciona a importante crítica que o ensaio que tenho citado dirige contra a ideia de uma "finalidade" das sociedades humanas. Tal como a comunicação também a sociedade não possui verdadeiramente nenhum fim fora do ciclo das comunicações em cadeia ${ }^{14}$. Os sistemas sociais dão-se no permanente retomar do fluxo das comunicações. A ideia de "fim" só poderia aqui receber algum sentido se a colocássemos, à partida, do exterior do próprio fluxo comunicativo, numa posição de evidente exterioridade, como de certa forma foi pretensão das representações idealizadas da sociedade que subordinaram o ciclo da comunicação a uma meta representada.

Mas como se refere a comunicação à consciência? É a propósito da resposta a esta questão que N. Luhmann aplica as duas noções de "meio" e de "forma" e de "acoplamentos frouxos" e "acoplamentos rígidos".

A comunicação utiliza a consciência como "medium". Nesta medida, a consciência permanece para o sistema da comunicação como "invisível": das beteiligte Bewußtsein bleibt für die Kommunikation unsichtbar ${ }^{15}$.

Os acoplamentos operatórios entre consciência e comunicação têm o seu lugar ao nível da evolução dos sistemas sociais e não de fora deles. É na evolução que podemos perspectivar estes pontos de acoplamento.

Os acoplamentos entre comunicação e consciência dão-se na linguagem, na escrita e na divulgação da imprensa ${ }^{16}$. Mas é possível conceber outros nódulos de articulação. Nestes, se geram possibilidades de ajuste entre o tempo da comunicação e o tempo da consciência sem redução mútua.

A linguagem e a escrita asseguram o acoplamento evolutivo da consciência e da comunicação, na medida em que ambas fazem parte de ordenamentos simbólicos que permitem transcrever o universo operatório

13 Idem, Ibid., p. 129.

14 Idem, Ibid., p. 121.

15 Idem, Ibid., p. 119.

16 Idem, Ibid., p. 120-121. 
de uma mediante o universo operatório da outra. Mas este acoplamento lido do lado da consciência não tem o mesmo valor que lido do lado da comunicação. Do lado da comunicação, a linguagem e a escrita são especialmente importantes porque asseguram para a autopoiésis da comunicação a função de "conservação da adaptação" (H. Maturana) ${ }^{17}$. Do ponto de vista político ambas garantem a referência à acção mediante a publicística e a actividade parlamentar. Mais adiante tratarei de esboçar a questão de saber se os acoplamentos vão apenas até aos sedimentos simbólicos da linguagem ou se não é necessário ir mais longe, até ao imaginário.

No que se refere à expressão simbólica, como é que a consciência pode ao mesmo tempo ser um sistema estruturalmente determinado e um "meio"? A diferença entre meio e forma deve ser entendida também ao nível da linguagem e da possibilidade de ela assegurar um ajustamento da comunicação e da consciência, gerando assim o acoplamento ${ }^{18}$.

A formação de frases e de conteúdos de pensamento é qualquer coisa de sempre evanescente, pois as frases agora formadas dão de imediato lugar ao silêncio e à ausência de fonação e de significação associada ou ao espaço vazio entre as palavras do texto escrito. É esta fluidez da linguagem que dela faz um "meio". As frases que se isolam nesse fluxo são como formas definidas emergentes do meio. Mas não há qualquer regra que defina o que fica e o que vai, o que se actualiza "agora" ou o que se esvai no plano da virtualidade. Esta plasticidade da relação meio-formas garante um nexo entre a temporalidade da associação das ideias, que pertence ao tempo da consciência, e os elementos que vão alimentar o ciclo das conexões comunicativas, que possui uma ancoragem na interacção mas cuja temporalidade deixou logo de estar referida a uma unidade da apercepção.

A instabilidade e a incerteza na formação da linguagem explicam o recurso à memória. $\mathrm{O}$ problema de saber se a comunicação tem memória deve igualmente colocar-se a este propósito, embora não possamos aqui dar resposta a esta dificuldade.

Na medida em que a comunicação se pode reproduzir a ela própria com o auxílio da linguagem, ela assume assim uma referência à consciência e está com esta forçosamente acoplada, pois a linguagem está também em continuidade com o fluxo das vivências e das acções. A consciência surge assim como participando do universo da comunicação ao mesmo tempo como meio e como sistema estruturalmente determinado e autónomo, o que só é possível na base da autonomia autopoiética de cada um dos sistemas.

${ }^{17}$ Idem, Ibid., p. 117.

${ }^{18}$ Cf. Idem, Die Gesellschaft der Gesellschaft, o. c., vol. 1, p. 190 e ss. 
Uma das propriedades importantes da relação entre comunicação e consciência reside no facto de a primeira se deixar "irritar" exclusivamente pela segunda, não sendo possível reconhecer uma qualquer influência directa dos mecanismos neurofisiológicos sobre a comunicação. As influências do meio envolvente físico só podem abrir ou fechar uma comunicação mas não influenciá-la no sentido próprio do termo.

Relativamente ao carácter autopoiético da comunicação sustenta $\mathrm{N}$. Luhmann que a comunicação "comunica dentro de si mesma" não sendo nunca perturbada ou influenciada por factores exteriores aos acoplamentos com a consciência necessários para manter ou reproduzir operações de tipo comunicativo.

Fora do que é necessário para assegurar a reprodução das operações de tipo comunicativo não se pode falar de uma total integração ou fusão entre sistemas baseados na comunicação e sistemas baseados na consciência. A relação entre ambos está, portanto, dependente de necessidades operatórias precisas de cada um deles e não tem um estatuto ontológico independente.

O reconhecimento implícito ou explícito da autonomia dos sistemas baseados na comunicação em relação à consciência e à percepção (e à acção) tem as suas consequências na geração de terminologia para esquematizar a experiência do mundo.

O conceito moderno de indivíduo é um dos mais significativos efeitos de esquematizações cruzadas entre comunicação e consciência, mas pressupondo a autonomia de cada uma. Isto significa que o indivíduo da sociedade moderna não ocupa um lugar ontologicamente determinado ou, em outra formulação, ele não constitui aquilo de que a sociedade é feita. Antes de tudo, o que pode ser afirmado é que o conceito histórico de indivíduo constitui um efeito semântico da diferença entre comunicação e consciência e, por isso, requer a semântica da sociedade moderna ${ }^{19}$.

A diferença entre comunicação e consciência esquematiza-se de um modo do lado da consciência e de outro modo do lado da comunicação. A fórmula do "indivíduo livre" da modernidade, interpretado como "humanismo" pelos intelectuais, mas que possui um alcance semântico não redutível aos humanismos, ambicionou consagrar um âmbito uniforme e homogéneo aos dois lados da esquematização, criando com isso a sugestão de um sujeito da História e da Política identificado com o "Homem". Se

${ }^{19}$ Idem, "Individuum, Individualität, Individualismus" in Gesellschaftsstruktur und Semantik, o. c., vol. 3, pp. 149-258: E. Balsemão Pires, „O Pensamento de N. Luhmann como teoria crítica da Moral“ in J. M. Santos (ed.), O Pensamento de N. Luhmann, Covilhã, 2005, pp. 253-280. 
sujeitarmos a escrutínio a ideia de "indivíduo livre" da modernidade sabemos que estamos a referir dois esquemas diferentes e não um só. A equívoca unidade entre comunicação e consciência que se descobre na história terminológica do indivíduo livre da modernidade, na ideia de Homem dos humanismos, significa, por isso, uma forma com dois lados que se co-possibilitam e não uma designação de um ser no mundo. Mais incisivamente eu diria que se trata de uma fórmula sem referente, que extrai da impossibilidade de uma coesão rigorosa entre comunicação e consciência a razão de ser das proclamações retóricas dos intelectuais. Em suma, trata-se de uma fórmula da co-possibilidade operatória. O autor de A Sociedade da Sociedade foi bastante preciso quando clarificou esta dupla face nos seus efeitos operatórios: uma mais elevada disponibilidade para a comunicação, do ponto de vista da sociedade; uma mais elevada disponibilidade de possibilidades da acção, do ponto de vista da consciência.

A recusa em emprestar um estatuto ontológico à relação entre a comunicação e a consciência é um postulado da teoria dos sistemas, que possui a sua justificação na análise da evolução da sociedade moderna. A evolução da sociedade moderna que, em termos de cronologia histórica aproximativa começaríamos a datar de 1500, entendida como "história dos efeitos da selecção", demonstra ao historiador e ao sociólogo, mas especialmente a este último, a crescente fixação da autonomia da "sociedade" em relação à consciência, à vontade, em suma frente aos "sistemas psíquicos".

A falta de uma explicação adequada sobre este aspecto da evolução da modernidade comporta consequências pesadas para o discurso da Filosofia Política e em particular para a associação entre humanismo e moral. Entre outras consequências refiro a falta de vigilância crítica a propósito da pretensão de reduzir a complexidade das relações entre o sistema político e outros sistemas da sociedade moderna a uma questão de "bons" e "maus" argumentos em matéria de discurso político. Uma parte significativa do pensamento moral e político contemporâneo nem sequer discute o tema da opacidade operatória entre consciência, vontade e comunicação e julga poder estabelecer uma relação directa entre o que é tido por argumento bem fundado ou por discurso legitimador, o cálculo político de agentes apostados em vencer em acções estratégicas e o sistema político como resultado histórico de selecções de possibilidades. As oposições binárias próprias das convenções morais servem para este discurso traçar o que toma como adequado, vantajoso ou "apto a vencer" nos cálculos racionais estratégicos, ou pelo seu contrário, relativamente à estratégia política. Procedendo assim, uma parte da Filosofia Política que hoje se escreve (ou se "pratica") oscila entre a orientação normativa da preceptiva tradicional, o discurso da "crítica" ou o discurso legitimador dos políticos. 
Para esta observação da sociedade moderna, a autonomia crescente dos sistemas sociais, assente na independência operatória da comunicação frente à consciência, não é por si mesma impeditiva da continuação das anteriores formas da argumentação moral e política fundadas na crença em uma influência das consciências umas sobre as outras, daqui sendo de esperar resultados na forma objectiva da sociedade ou no que a "sociedade e o estado devem ser". O principal obstáculo com que se depara este tipo de discurso é o da impermeabilização crescente da esfera da decisão política relativamente à argumentação moral e, por outro lado, o facto de as formas da argumentação moral serem cada vez mais aquilo que podem ser, ou seja, determinações que resultam de arranjos muito relativos e instáveis entre o grau da evolução da consciência e o grau da evolução da comunicação.

Este tipo de pensamento moral em atraso relativo às condições de reprodução da comunicação da sociedade moderna, entretanto mundializadas, não chega a ter em conta as suas próprias circunstâncias. Não compreende que é, desde logo, um discurso da observação da sociedade dentro da sociedade ${ }^{20}$ e que depende de uma determinada forma histórica de selecção das possibilidades práticas que se dá de uma maneira nos sistemas sociais e de outra forma nos sistemas psíquicos. Quando aplicada ao sistema político da sociedade moderna na sua actual forma de "sociedade mundial" a terminologia usada naquela forma do pensamento moral é representativa das semânticas redutoras. As semânticas redutoras mobilizam grandes categorias simbólicas e "meios de comunicação simbolicamente generalizados" para organizar a comunicação segundo temas difusos: bem / mal, justo / injusto, poder / impotência, felicidade / infelicidade, etc. A literatura filosófico-política recente mostra-nos como, neste domínio, a terminologia é muitas vezes típica das semânticas redutoras. Naturalmente, com esta caracterização não se pretende negar poder sugestivo à argumentação moral, na medida em que ela for mobilizada pelo sistema político para os seus fins próprios. O que convém é não confundir toda a Filosofia Política com a argumentação moral.

Se queremos entender o significado da Filosofia Política na sua relação interna com a sociedade moderna, sobretudo se pretendemos saber que relação liga a estrutura da sociedade moderna com um discurso cuja

${ }^{20}$ N. Luhmann considerou a descrição da sociedade dentro da sociedade como um modelo de observação de que a sociologia tinha forçosamente de partir, mas o que ele disse sobre a Sociologia pode aplicar-se, mutatis mutandis à Filosofia Política. Veja-se o conceito de uma "autologia reflexiva" em N. Luhmann Die Gesellschaft der Gesellschaft, o. c., vol. 2,1128 e ss. 
proveniência histórica se não pode confundir, apenas, com a modernidade temos, então, de esclarecer que condições existem na sociedade moderna para garantir a sua própria observação e que lugar atribuir, então, à Filosofia Política nas formas dessa observação. Novamente nos podemos aqui socorrer de algumas ideias da teoria dos sistemas sociais.

Só por abstracção é possível desvincular as operações que os sistemas realizam da operação da observação.

A observação é também uma operação e aquilo que a caracteriza é o facto de ela tanto se poder exercer pela consciência em relação à comunicação como pela comunicação em relação à consciência. Wir brauchen, um dies sagen zu können, einen Begriff des Beobachtens, der nicht vorab schon psychisiert verstanden, also exclusiv auf Bewußtseinssystem bezogen wird ${ }^{21}$, concluia N. Luhmann.

A separação operatória entre consciência e comunicação não impede, então, que se dê uma recondução ao nível da observação e do observador.

O que garante a continuidade entre a consciência e a comunicação pode ser a existência de um "mundo" dotado da consistência que a "metafísica da coisa" lhe havia atribuído, como qualquer coisa de independente das observações?

Existe ainda um mundo como base comum da consciência e da comunicação a suportar os seus ciclos autopoiéticos autónomos? Trata-se de um problema para um outro estudo.

Para o nosso objectivo aqui interessa observar que a teoria dos sistemas emprestou desde muito cedo à ideia de realidade a nota da objectividade sistémica que distinguiu do que numa certa tradição se tomou como objectividade metafísica. Para diferenciar o seu conceito de objectividade da objectividade metafísica a teoria dos sistemas tem-se referido a dois conceitos fundamentais: o conceito de operação e o de auto-referência ${ }^{22}$.

Se os sistemas parciais da sociedade moderna são constituídos por ciclos operatórios dotados de consistência interna a sua objectividade não pode ser definida, todavia, como objectividade de tipo metafísico ${ }^{23}$. Mas

21 Idem, "Wie ist Bewußtsein an Kommunikation beteiligt" in Idem, Aufsätze und Reden, o. c., p. 125.

22 Cf. Idem, Beobachtungen der Moderne, Opladen, 1990, p. 25-41 e 58-60.

23 Uma operação não é uma entidade do tipo das "substâncias" embora as operações sejam dotadas de um certo tipo de objectividade, precisamente aquela que lhes é assegurada pela sua capacidade de originar operações do mesmo tipo. Uma operação existe por meio de um cálculo, quer dizer, existe por meio de outras operações articuladas estruturalmente de modo a originar resultados que repetidamente se vão utilizar em novas operações. As operações remetem para outras operações num processo gerativo. A objectividade de uma 
trata-se, antes, de sistemas de sentido adquiridos como resultado de uma evolução histórica determinável, como "história da selecção" do sentido.

Operações e operações de sentido geram "objectividades" que não se definem nos quadros da "objectividade da coisa" da metafísica clássica. Isto explica por que motivo na Sociedade da Sociedade N. Luhmann declarava que a sociedade não é "nem sujeito nem objecto" (weder Subjekt noch Objekt ${ }^{24}$ ). Este "weder... noch" define o quadro de uma "objectividade operatória".

O tipo de operação e de forma que diferencia a sociedade de outros sistemas autopoiéticos é, pois, a comunicação na sua diversidade, produzida no "meio" do sentido 25 .

Partindo do encerramento sobre si dos sistemas autopoiéticos é necessário concluir que não existe verdadeiramente nenhum "contacto" do sistema com o "exterior" a si, com o "meio ambiente". Por essa razão, a comunicação contacta com outras comunicações e o que se chama meio ambiente só no processo de processamento da comunicação pode ter lugar. A consequência destas premissas não se faz esperar: os sistemas operam, apenas, sob a ilusão de um contacto com o meio ambiente.

Deste ponto de vista, a sociedade moderna, que a teoria dos sistemas sociais, na continuidade da tradição sociológica, identificou com o tipo da "diferenciação funcional" 26 , não se observa sob a categoria de "mundo"

operação é-lhe garantida mediante as operações para que remete e graças ao processo gerativo em que as operações se encontram associadas para produzir certos resultados. "Geratividade" e conectividade são os dois aspectos do que poderemos chamar "objectividade operatória". A "objectividade operatória" é um postulado muito interessante para uma teoria evolutiva da sociedade, em especial da "sociedade moderna", que procura dar resposta à geração dos fenómenos da autonomia sistémica como aqueles que se referem às aquisições de sentido relacionadas com os diversos sistemas parciais da sociedade, como o sistema político, o sistema económico, o sistemas dos "mass-media", o sistema da arte, o sistema da religião, etc. É neste quadro de uma objectividade operatória que pode ter sentido falar-se em algo como uma "ontologia operatória".

${ }^{24}$ Cf. N. Luhmann, Die Gesellschaft der Gesellschaft, o. c., vol. 2, 868-879.

${ }^{25} \mathrm{Na}$ medida em que um sistema de comunicação se individualiza mediante a diferença que institui entre si mesmo e o diferente de si, entre sistema e meio-ambiente, ele mobiliza duas formas de referência, a que importa fazer alusão: a auto-referência e a hetero-referência (Selbstreferenz/Fremdreferenz). Não há possibilidade de conceber a unidade entre estes dois aspectos da referência. Isto elucida-se mediante a evidência de que na comunicação é sempre qualquer coisa que não pertence à ordem puramente comunicativa que é actualizado ou modificado. Todavia, isto passa-se, exclusivamente, de dentro da própria comunicação. A hetero-referência é sempre, por isso, algo de incluído na auto-referência da comunicação. Cf. N. Luhmann, Idem, Beobachtungen der Moderne, o. c., p. 26.

26 Para uma precisão conceptual remeto o leitor para: E. Balsemão Pires, A Sociedade sem Centro, Azeitão, 2004. 
ou mais precisamente de "mundo ético" (naquela acepção convencional já referida), de cosmos inter-humano ou à luz da noção antiga de "ordem", mas sob o ponto de vista da complexidade operatória e da autonomia sistémica parcial que dentro de si gera. Esta nova descrição (observação) da sociedade moderna tem consequências filosóficas muito profundas, especialmente para a auto-compreensão da Filosofia Política.

A observação ontológica do "mundo ético" que se baseia no conceito de "ordem" pode servir a finalidade de explicitar efeitos de coordenação entre as formas da vida, as formas da consciência e as formas da comunicação, mas apenas na medida em que for entendida em articulação com essa necessidade de coordenação, não por si própria.

Não há um conceito de mundo porque há o mundo ou a "ordem", mas há descrições que se servem do conceito de mundo para tornar possíveis esquemas de coordenação entre autopoiesis autónomas.

A própria História da Filosofia Política atesta a crise do conceito de ordem do pensamento clássico como fundamento das observações da sociedade, na época moderna. Distinguindo entre uma Filosofia da Ordem e uma Filosofia da Liberdade a auto-descrição da Filosofia Política na sua História revela como as noções de estabilidade, fixidez, imutabilidade ou regularidade da ordem não são fundamentos inconcussos do que se toma por realidade política. Cogitando um termo adequado para identificar a Filosofia Política da sociedade funcionalmente diferenciada se diria que ele terá de ir mais além do pensamento da liberdade e deverá ser pensamento da complexidade. A Filosofia Política da nossa era terá de dar conta da relação incerta entre a auto-compreensão histórica da liberdade e a forma da complexidade típica da sociedade funcionalmente diferenciada. Ritmada por estas três pautas do tempo histórico - a da ordem, a da liberdade e a da complexidade - a História da Filosofia Política exprime na linguagem do sintoma a forma como a sociedade moderna gerou e continua a gerar formas de observação adequadas ao seu modo de processamento da comunicação e exprime ainda o modo como, na sua evolução, ela se distanciou da semântica da Ordem ou da unidade de todas as coisas para traduzir aquilo que está implicado na formação e no processamento do sentido em sistemas psíquicos e em sistemas sociais ${ }^{27}$.

${ }^{27}$ Há um trabalho filosófico a desenvolver relativamente aos problemas que A Sociedade da Sociedade suscitou a respeito da terminologia filosófica da tradição clássica e não apenas naquilo que se refere ao estatuto da "Semântica da Velha Europa". Tive a oportunidade de desenvolver uma parte destas questões no trabalho E. Balsemão Pires, "Mitologia e Contingência (esboço de compreensão da Filosofia Prática como Mitologia da Razão e da sua Crise 1789 - 1989)" in A Borges / A P. Pita / J. Ma André (coord.), Ars Interpretandi. Diálogo e Tempo. Homenagem a Miguel Baptista Pereira, Porto, 2000, 303 - 399. 
Se o pensamento clássico da ético-política estava organizado segundo a forma da orientação da consciência humana para a acção e aqui fazia repousar o essencial da sua reconstrução justificativa, ou "crítico-racional" no caso da semântica avaliativa dos modernos, da "realidade social" e das decisões políticas, já com a distinção entre consciência e comunicação, que em parte acompanha a constituição da Sociologia como ciência, a forma da relação consciência-acção deixa de se poder considerar exclusiva para observar e descrever a "realidade social".

Contudo, a caracterização de tipo evolutivo e estrutural das formas da comunicação e da sua modulação sistémica tem estado apenas disponível de fora do discurso da Filosofia Política, no discurso da ciência, como Teoria da Sociedade moderna. A capacidade da Filosofia Política para designar e descrever as formas da comunicação à luz do seu conceito de racionalidade torna-se limitada e parcial se ela se auto-restringe ao seu núcleo semântico tradicional baseado na relação consciência-acção. Ao contrário, não deve a Filosofia Política ter a ambição de aceder até aos limites históricos da sua herança semântica e, neles, abrir-se para as mutações a que o seu futuro a sujeita?

Para continuar a responder a este problema do estatuto das observações e descrições da sociedade moderna precisamos de um lugar preciso para poder identificar "entre" os sistemas psíquicos e os sistemas sociais autonomizados um espaço em que a coordenação da autopoiesis de ambos se observou e descreveu com recurso ao imaginário e à estrutura simbólica da linguagem. Este é também o espaço em que se moveram as "semânticas redutoras" desde o movimento incessante da auto-reprodução das autopoiesis parciais até às estases simbólicas e imaginárias.

Entre o movimento e as estases do movimento situaremos o conceito de um duplo meio-ambiente, cuja unidade, desde sempre já perdida, alimenta, todavia, como um vazio produtivo, as estruturas do imaginário do mesmo modo que as grandes construções imaginárias dos intelectuais da modernidade.

\section{II - O imaginário político moderno e a História dos intelectuais}

O que agora gostaria de sustentar é a ideia de que aspectos significativos da Filosofia Política como a vemos investigada hoje e no passado resultam de determinações do imaginário social e político, quer dizer, prendem-se, directamente, com esquemas de coordenação de autopoiesis parciais e, desde $\operatorname{logo}$, com a coordenação entre sistemas psíquicos (assentes na consciência-percepção-memória) e sistemas sociais (assentes na comunicação). Com este papel coordenador está associada a observação 
da sociedade moderna e, aqui, se pode ilustrar o papel dos intelectuais e o imaginário de que foram portadores.

Um dos principais problemas que há que enfrentar na relação da Filosofia Política com o entendimento sistémico da sociedade moderna é precisamente o valor da reconstrução normativa da sociedade e do sistema político em especial, que filósofos e intelectuais ainda hoje perseguem, baseados na crença em uma continuidade "natural" entre consciência, acção e comunicação, encurtando deste modo a complexidade dos laços que unem os dois sistemas de processamento de sentido. A isto alguns chamarão pensamento da totalidade, e não sem razão. O conceito de totalidade da consciência tardo-moderna está embebido em representações que não se caracterizam somente pelo recurso a formas simbólicas da linguagem, mas exprimem condições do imaginário.

Comecemos pela referência a um sintoma.

$\mathrm{O}$ receio que se alastrou entre as elites intelectuais relativamente a uma "perda de centro" na sociedade moderna não é um tema novo, mas é certamente um fenómeno imaginário tardo-moderno. Este receio é legítimo e a perda de centro é um facto desde que a diferenciação funcional se tornou na forma de diferenciação predominante da sociedade moderna e ela traz consigo, para além disso, a perda da "totalidade".

Mas qual o significado sistémico desta descrição da sociedade?

Quando nos referimos a uma tonalidade afectiva relacionada com uma representação referimo-nos, obviamente, a uma possibilidade de sentido dos sistemas psíquicos e quando especialmente está em causa uma representação da sociedade tomada como objecto da representação, estamos a tomar a sociedade como o meio ambiente do sistema psíquico.

Entre os sistemas psíquicos e o sistema social os meios ambientes são reciprocamente permutáveis e aquilo que para um é sistema é para o outro meio ambiente.

$\mathrm{Na}$ medida em que o meio ambiente é para um sistema um conjunto de possibilidades aberto para resolver o paradoxo da auto-referência, por meio da geração de uma hetero-referência, pode dizer-se que os sistemas psíquicos e o sistema social têm um no outro a possibilidade da sua "destautologização".

A sociedade moderna resolve o paradoxo da sua auto-referência gerando uma elevada disponibilidade de comunicação para os indivíduos e estes últimos resolvem a sua própria "paradoxia" encontrando na sociedade "liberdade" para a realização das suas finalidades.

Nas condições estruturais da modernidade, em que os indivíduos não são tomados como "membros" da sociedade, esta última é, para eles, possibilidade de comunicação. As autopoiésis dos sistemas psíquicos e dos sistemas sociais podem reciprocamente correlacionar-se na condição de 
uma decifração mútua na base auto-referencial de cada um: os sistemas psíquicos encontram na sociedade as condições da sua liberdade e a sociedade encontra nos sistemas psíquicos os suportes para a efectividade de conexões comunicativas associadas a acções.

Podemos dizer que o que torna possível a efectivação da tradução de uma autopoiésis na outra é, num dos lados, a liberdade e, no outro, a comunicação.

Retomemos, agora, o sintoma, quer dizer, o tema da "perda de centro".

O receio da "perda do centro e da totalidade" é uma descrição de uma resposta afectiva que supõe uma semântica pré-moderna e que remete para diferenças estruturadas numa moral convencional. Como percepção "cultural", a percepção de "perda" ocorre quando se observam aspectos novos com base em categorias de uma tradição volvida. A "perda" não é uma ausência no "mundo objectivo" mas uma falha no horizonte interpretativo.

O que pretendo sustentar é que "perda do centro" e "perda da totalidade" são dois sintomas que resultam da longa evolução semântica que conduziu a um estado de saturação do que designei por história contraditória do humanismo ${ }^{28}$.

As bases da cultura humanista que, desde o renascimento, pretendiam desvincular a consciência e a acção da pressão de autoridades exteriores ao próprio indivíduo levaram, contra a sociedade do seu tempo, à formação de um conceito de autonomia que só pode ser compreendido como exterior a qualquer imposição social, o que acabou por ter por consequência a emergência histórica de uma sociedade à medida da exigência do humanista. Mas este último continuará a exigir da sociedade que contemple todas as expressões da sua autonomia.

O que originou o humanismo como ideologia de pressão moral na sociedade moderna fez, por fim, prescindir desse mesmo humanismo e trouxe a crítica da sua ilusão.

Aquilo de que se trata é da dualidade interna do indivíduo moderno. Pela sua simplicidade ele pretende manter-se como a fonte moral da sociedade e exige que a sociedade o reflicta, mas pela sua multiplicidade e mobilidade internas, pela sua liberdade, ele nega-se a si próprio incessantemente como imagem unitária do "mundo ético" e de si mesmo.

Por seu lado, a sociedade moderna, funcionalmente diferenciada, não aceita reflectir a simplicidade dos indivíduos, aquilo que seria a imagem imóvel da multiplicidade, mas reflecte, ao contrário, o perpétuo movimento da negação do ser simples da individualidade, gerando para ele chances loc. cit.

${ }^{28}$ Cf. Idem, "O Pensamento de N. Luhmann como teoria crítica da Moral" art. cit. in 
comunicativas sempre novas e uma larga indiferença relativamente a conteúdos expressivos determinados ${ }^{29}$.

Se é possível fundamentar a ideia geral do carácter "extra-social" do indivíduo como um resultado de uma conjugação historicamente muito complexa da semântica do conceito e da evolução estrutural da sociedade moderna, é importante também esclarecer que consequências se podem esperar para a ideia de "totalidade" do mundo social.

Nos séculos XIX e XX, a política prática de importantes sectores da sociedade partiu quase sem discussão da possibilidade de descoberta da totalidade das relações sociais entre os homens, do seu conhecimento por parte dos militantes políticos e da possibilidade de "transformação do mundo".

O conceito de totalidade designava a imagem coerente para estruturar os fins da acção política, o que implicou tomar a sociedade simultaneamente como um objecto de descrição, um destinatário da acção e da comunicação e fim do agir. A crença generalizada e nunca discutida dizia que a sociedade podia e devia ser transformada pelos homens à luz de ideais que só eram possíveis graças ao poder de representação e evocação deste "todo".

Numa obra recente, Wolf Lepenies interpretou a genealogia dos intelectuais europeus na sua relação com a política mostrando como o intelectual está frente à "unidade do todo", prometida pela acção do soberano, como perante uma dupla impossibilidade de sincronia: a impossibilidade que resulta da idealização utópica e a impossibilidade que é efeito da melancolia ${ }^{30}$. Nos grandes temas-moldura da utopia e da melancolia encontram-se algumas das imagens mais genuínas da relação impossível entre o filosofo, ou o intelectual, e o soberano naquilo que se prende com a capacidade da designação da totalidade.

Podemos ver nesta tradição do grande humanismo europeu e norte-americano uma tentativa do indivíduo para encontrar na sociedade as condições da sua própria satisfação e realização como "sujeito livre". Na medida em que a descrição destas condições se associava à necessidade de agir, assim se modificava, também, o humanismo numa moral, extraindo sempre da moral convencional a distinção de forte perfil polémico entre "bem" e "mal".

29 Neste aspecto é de interesse filosófico particular a reflexão sobre N. Luhmann, "Individuum, Individualität, Individualismus" in Gesellschaftsstruktur und Semantik, o. c., vol. 3, especialmente p. 175 e ss.

30 W. Lepenies, Qu'est-ce qu'un intellectuel européen? Les intellectuels et la Politique de l'Esprit dans l' Histoire européenne, Paris, 2007. 
Esta concepção da totalidade da sociedade da herança humanista está associada, por conseguinte, em parte, a uma moral convencional.

O que, na acepção que estamos a reter, qualifica uma determinada visão da sociedade como visão moral da sociedade é a criação de um "meio" imaginário em que os sistemas psíquicos, o que vulgarmente chamamos com facilidade "os homens", atribuem à sociedade comportamentos, normas e valores que estão situados originariamente na relação interna entre simplicidade (identidade) e multiplicidade dos possíveis do indivíduo.

Com isto os sistemas psíquicos reproduzem a sua auto-referência pois captam o meio ambiente social a partir da sua autopoiésis, exclusivamente.

A visão moral da sociedade permite facilmente transgredir a auto-referencialidade do indivíduo sobrepondo-se a outros domínios auto-referentes, sem contactar com estes últimos, mas impondo-se a eles.

A crença num universo ordenado de acordo com o conteúdo das motivações individuais generalizáveis em contextos comunicativos sistémicos é o que permite continuar a discorrer sobre o "bem comum" e sobre um "mundo" eticamente ordenado.

$\mathrm{Na}$ sociedade moderna já distanciada dos princípios que orientavam a formação das elites dirigentes das sociedades estratificadas, a linha contínua nascida desta convergência entre o que representa a motivação e o que pertence ao discurso normativo é produto de mecanismos de equilíbrio na "interpenetração" ${ }^{31}$ entre sistemas psíquicos e sistemas sociais.

Por meio da visão moral convencional da sociedade se torna possível verter ilusoriamente o que a sociedade é em termos de operações de comunicação no que o sistema psíquico é em termos de operações de consciência / acção. De facto, a visão moral da sociedade é aquela que se baseia na possibilidade de traduzir comunicações em conteúdos de consciência / acção, mas abstraindo da conexão complexa entre liberdade da acção e comunicação. O discurso da moral convencional usa as

31 Introduzido por N. Luhmann no capítulo 6 de Soziale Systeme, o conceito de « interpenetração » está destinado a uma carreira filosófica (e sociológica) significativa desde que se compreenda que com a interpenetração de sistemas psíquicos e de sistemas sociais não se pretende restaurar a uniforme concepção da "natureza humana". O conceito representa, ao contrário de qualquer intenção uniformizadora, a complexidade que é necessário ter em conta quando referimos que os sistemas sociais estão forçosamente acoplados a sistemas psíquicos. Este "estar forçosamente acoplados" não quer dizer que tudo o que a comunicação no seu ciclo próprio utiliza e cria esteja forçosamente relacionado com uma consciência desse ciclo comunicativo. Daqui retiramos a conclusão que o interesse de uma investigação sistémica sobre conceitos como "mundo" ou "homem", por exemplo, está em revelar como nesses conceitos aparentemente "simples" se esconde a complexidade e irreversibilidade de conexões contingentes. A «interpenetração» tem, pois, de se entender como um conceito da irreversibilidade, da contingência e da improbabilidade dos nexos da co-possibilidade de sistemas psíquicos e de sistemas sociais. 
condições comunicativas da sociedade moderna ignorando a sua forma, quer dizer, ignorando que a comunicação é sempre reproduzida com um ganho interno, ou seja, reproduzida para gerar sempre nova comunicação, ou chances inéditas.

É fácil concluir, portanto, como a ideia de totalidade da visão moral da sociedade é fruto da ilusão de uma unidade entre o tempo da consciência e o tempo da comunicação.

Uma tal ilusão tem o seu desenvolvimento, a sua produtividade própria, as suas "conectividades". Não é pelo facto de ser "ilusória" que ela perde densidade ou deixa de produzir efeitos. Mas devemos dizê-lo: a produtividade da ilusão de uma comensurabilidade entre tempo da consciência e tempo da comunicação diz respeito à ordem do imaginário.

Quando dizemos "esta sociedade é a boa!" e queremos orientar a nossa vida e a vida dos outros por esta imagem total estamos apostados em manter a ilusão de que é possível esgotar a comunicação na consciência e na acção e que entre as duas operações (a operação "consciência-acção" e a operação "comunicação") existe um laço interno inquestionável e sem dissociações.

Quem diz "isto é bom!" e "aquilo é mau!" num argumento que goza da generalidade das representações morais quer terminar uma conversa e não continuá-la, ele pretende reduzir o tempo da comunicação ao tempo da sua consciência nos limites da sua representação do mundo.

Com estas características gerais, a orientação normativa para a sociedade e para o político constitui um aspecto da tradição da Filosofia Política assim como da cultura política que baseou o papel dos "intelectuais". Sabemo-lo pelo menos desde Platão, e vimo-lo repetido em Aristóteles, que todo o filósofo é mitófilo, um fazedor de imagens adequadas aos seus destinatários, um estratega da imaginação.

Na sequência de Maquiavel, Gabriel Naudé, referindo-se a Tito Livío e a Tácito, mostrou o laço que a política mantém com o imaginário e em especial com o imaginário religioso, na época da fundação dos estados e nas estratégias para a sua defesa ${ }^{32}$. Nisto, a modernidade mostrava ter perfeita consciência da importância dos profetas para a consolidação do poder nas primeiras nações e das imagens poderosas que esses homens geraram para manter desperto o sentimento de piedade e respeito nos povos jovens, tema a que Espinosa e G. B. Vico regressaram. Mas em G. Naudé se trata já de uma consciência da relação estrutural entre a política e o imaginário. É esta relação que, mudadas as circunstâncias históricas, os "intelectuais" da época moderna e contemporânea estarão em condições para consolidar mesmo sem a religião tradicional.

${ }^{32}$ G. Naudé, Considérations Politiques sur les Coups d' État, Paris, 1988 (reed. 2004), especialmente pp. 111-116. 
Uma das primeiras notícias do equivalente ao grupo social que mais tarde se chamará "os intelectuais" europeus aparece na noção de uma Respublica litteraria em 1417, que os historiadores consideram o primeiro esquisso do que se irá designar por "República das Letras". Em 1642 o conceito de Republique des Lettres foi utilizado como um conceito equivalente ao conceito de "público", pelo parlamentar francês Claude Sarrau. Depois de, em finais do século XVII, pela intervenção de Anton Maria Salvini, da Academia de Florença, a ideia de uma "Republica dos letrados" ter conhecido a clara identificação política com a aproximação desta classe dos eruditos a um governo paralelo, distribuído por todo o mundo, a transformação ulterior da noção de "lettres" irá aproximar também esta ideia de Republica dos "sábios" ou dos "eruditos", até que no artigo "Catius" do Dictionnaire Historique et Critique de P. Bayle o autor diz que tal Republica é como um "estado extremamente livre" onde não se conhece outra coisa a não ser o impulso para descobrir a verdade. Ideias semelhantes vão sublinhar o carácter livre desta associação assim como o facto de estar distribuída por todo o mundo. Em 1718, Cristoph August Heumann, um professor de Göttingen, comparava directamente a Republica das Letras à "Igreja Invisível". Por fim, na ordem das identificações e aproximações, no artigo "gens de lettres", da Enciclopédia (1757), Voltaire conclui que os letrados são polimatos, a que faz falta o "esprit philosophique" para obterem total êxito. Neste sentido, os "letrados" tornar-se-ão, desejavelmente, na verdadeira acepção do termo, "filósofos"33.

A relação entre o iluminismo, o nascimento do ideal dos intelectuais europeus no espírito da Republique des Lettres

ideal do seu "Estado livre" que garante a estes homens a "autoridade" para se tornarem legisladores do estado real. Contra estas pretensões se ergueram os pensadores conservadores, desde logo E. Burke nas suas Considerações sobre a Revolução Francesa (1790), obra em que são

${ }^{33}$ H. Bots / F. Waquet, La République des Lettres, Paris, 1997, especialmente pp. 11-61. 
visados directamente os "homens de letras", tidos por responsáveis pela instigação de uma campanha contrária à "religião cristã"34.

Se seguirmos a genealogia do conceito de "intelectual" na cultura europeia dos finais do século XIX facilmente verificamos que no que se refere aos episódios relacionados com o "caso Dreyfus", num escrito do director da Revue des Deux Mondes, o termo apontava para "les gens qui vivent dans les laboratoires et les bibliothéques... les savants, les professeurs, les philologues" 35 , ou seja, as pessoas com educação superior que pretendem influenciar a vida pública. Neste artigo de Ferdinand Brunetière o termo "Intellectuels" era usado com sentido quase pejorativo e o motivo para esse uso negativo residia no facto de o autor considerar que todos estes homens de gabinete não possuíam para a "ordem social" mais valor que certos agricultores ou negociantes. A influência na "ordem social" dos "letrados" ou "classe culta"era, por isso, considerada exagerada relativamente ao valor real destes personagens. Mas em redor do "caso Dreyfus" o significado do termo conhece um amplo sucesso e passou a designar, tanto do ponto de vista interno como externo, o grupo dos que publicamente se manifestavam por "causas", por meio de abaixo-assinados ou por intermédio dos jornais, e cujo impacto dependia do prestígio conferido pela posse de um saber. Rapidamente também se dividem as opiniões relativamente à legitimidade destes novos actores sociais e é sabido como os escritores de direita, como M. Barrès, atacaram o poder social dos intelectuais em geral, considerando a sua influência contrária ao espírito da Nação ${ }^{36}$.

Sabemos como o "caso Dreyfus" constitui um dos primeiros acontecimentos políticos da História europeia em que a divisão entre a direita e a esquerda alcança um significado amplo, designando uma oposição entre "visões do mundo", uma luta entre "doutrinas compreensivas" e não apenas uma diferença política quanto à orientação do governo. Significativamente é neste ambiente que os "intelectuais" vão surgir, não apenas na forma terminológica (os termos aparentados com "intellectuels", "intellectuals", Intellektuelle" ou "Intelligentsia" datam de antes dos finais do século XIX) mas com um grau assinalável de auto-consciência de grupo ${ }^{37}$.

O sucesso que esta classe adquire na segunda metade do século XIX é fruto do que tornou possível a sua própria existência como grupo social: a imprensa e a difusão escrita das ideias. Os historiadores mostraram como

${ }^{34} \mathrm{Cf}$. C. Charle, Les intellectuels en Europe au XIXe siècle. Essai d'Histoire comparée, Paris, 1996 (reed. 2001), pp. 83 e ss.

35 Cit. in M. Winock, Le Siècle des Intellectuels, Paris, 1997 (reed. 1999), pp. 29-30.

36 Idem, Ibid., p. 31.

${ }^{37}$ C. Charle, o. c., p. 23. 
os antigos preceptores, que evoluíram entretanto para as ocupações mais típicas da "publicística", começaram por gerar uma solidariedade por exclusão para, seguidamente, se afirmarem, graças à imprensa escrita, por meio das suas próprias armas, no "espaço público". A ideia de "público" está, é claro, geminada com a formação de uma auto-consciência dos intelectuais ${ }^{38}$.

No século XVII podíamos encontrar já um determinado uso do conceito de "público" que ultrapassava as fronteiras da sociedade de "ancien régime". É possível descobrir ainda a ideia de uma determinada "opinião" atribuída ao público nos finais do século XVII, embora ainda falte a expressão como tal.

Alguns elementos semânticos foram já devidamente identificados na formação da expressão "público", nomeadamente naquilo que se refere à suposição de um reflexão da sociedade (a ideia de "opinião pública" servirá aqui de ilustração) e de uma capacidade para ajuizar por si mesmo.

Em 1693, Jean de la Bruyère, na sexta edição de Caracteres, havia atribuído ao público uma capacidade de juízo.

C. Dufresne-Rivière editor de Mercure Galant, num título de 1699, Amusements sérieux et comiques, tomou le public como uma instância independente dos espíritos individuais, capaz de ajuizar sobre os feitos dos "vivos e dos mortos".

Por outro lado, começa no mesmo período a ser utilizado o termo público na relação com o espaço e não apenas no que se refere ao leitor presumido de textos escritos.

No uso terminológico de The Spectator os locais públicos, como os cafés de Londres, são opostos aos locais privados, como os apartamentos privados dos frequentadores ${ }^{39}$.

De qualquer modo, as duas vertentes do conceito de público estão enlaçadas e recebem a sua unidade de sentido da literatura na forma de periódicos para instrução geral sobre questões morais.

$\mathrm{Na}$ medida em que na significação mais forte do conceito de público se situa o discurso escrito e os seus destinatários, é natural que tenha sido possível, em dada altura, definir a própria faculdade de leitura como o "público".

38 Da abundante literatura sobre o "espaço público" refiro a título exemplificativo: P. U. Hohendahl unter Mitarbeit von R. A. Berman, K. Kenkel, A Strum, Öffentlichkeit. Geschichte eines kritischen Begriffs, Stuttgart - Weimar, 2000.

39 Idem, Ibid., pp. 11 e ss. 
O periódico escrito, o café, o salão e o teatro são quatro concretizações do conceito de público tornados possíveis pelo seu valor diferenciador em relação ao Estado e ao Parlamento assim como frente à esfera privada.

Ao longo do estabelecimento do conceito europeu de "público" entre o século XVIII e a época das duas Guerras Mundiais delimitam-se três figuras do que chamo genericamente "intelectual": o intelectual como educador, o intelectual como agente do protesto moral e o "intelectual orgânico".

Zygmunt Bauman mostrou no seu estudo sobre Legisladores $e$ Intérpretes ${ }^{40}$ como a classe dos intelectuais europeus estabeleceu a sua ocupação em redor da prática educativa, desde logo na forma da educação dos príncipes e dos nobres segundo o ideal da virtude, na sua dupla dimensão da virtude individual e da virtude política. Os preceptores asseguraram um enorme sucesso à perspectiva da continuidade entre motivações virtuosas da conduta individual e o ideal do "bom" governo da coisa pública ${ }^{41}$. Daqui herdámos muito do que caracteriza a semântica moderna e contemporânea do discurso normativo, independentemente de o "letrado" e o "preceptor" terem sido ultrapassados, na sua posição de legisladores ideais, pela figura, mais modesta, mas que também já revelou sinais de crise e abandono, do intelectual como agente do protesto moral e, posteriormente ainda, pelo "intelectual orgânico".

O fio que une as três figuras do intelectual, que se torna mais acentuado nas duas últimas formas, reside no tipo especial de combate que consiste na luta pela supremacia na observação da sociedade. Não se trata directamente de combate político, mas de "luta cultural". A existência de "intelectuais" prova, de certo modo, que a observação da sociedade nunca está decidida naquilo que se refere aos sistemas psíquicos, às representações e às crenças. $\mathrm{O}$ facto de se travar um combate pela observação da sociedade revela, além do mais, como a verdade da moral dos intelectuais, ou o seu "dever-ser", consiste na sua dupla impotência por não poderem vencer ainda o seu oponente ou por não poderem transformar por completo as representações da consciência e as orientações normativas para a acção em formas da selecção sistémica. Concomitantemente, o público interpretará também esta situação moral de um "ainda não", característica do intelectual, na sua relação com o parlamento ou com o governo, sendo o "espelho moral da sociedade" mas em constante polémica.

${ }^{40}$ Z. Bauman, La Décadence des Intelectuels. Des Législateurs aux Interprètes (trad. do inglês), Arles, 2007, pp. 32 e ss.

${ }^{41}$ Sobre a significação de "virtude" na época moderna e a sua relação com a imagem da nobreza cf. Idem, Ibid., pp. 40 e ss. 
Num escrito de 1819-1820, A Philosophical View of Reform, o poeta Shelley, usando a expressão "Political Philosophy", dava a ver como a constituição republicana dos Estados Unidos, que ele gaba, fora o resultado das principais obras dos "filósofos" que, no campo das ideias, haviam preparado o terreno que depois a história real dos homens e dos povos viria a confirmar e concretizar, à luz do ideal de democracia. É com este sentido que daquele escrito do poeta se pode concluir a tese de que a história real corre em consequência da história intelectual, sendo como uma sombra projectada por esta última. A crença na relação entre norma do pensamento e história dos acontecimentos estava lançada e dela é exemplificativa a célebre frase deste escrito: "poets and philosophers are the unacknowledged legislators of the world" 42 . Shelley não esteve isolado na sua crença. Da sua perspectiva comungam os saint-simonianos franceses e já desde a década de 1820 que os discípulos de Hegel na Alemanha iniciavam um movimento publicista no sentido de tornar actuante o pensamento filosófico, cumprindo um anseio que fora o da geração do próprio Hegel relativamente à filosofia de Kant.

As transformações ocorridas no sistema político em virtude dos nacionalismos europeus trouxeram consigo consequências no plano da auto-consciência dos intelectuais. Entre essas consequências está o facto de se ter entretanto formado a ideia de uma tarefa colectiva, a ideia da "missão do intelectual", o "engagement" detectada em relação à auto-consciência pré-nacionalista dos intelectuais. Foi na verdade o desenvolvimento do nacionalismo europeu que acabou por tornar forçoso o aparecimento da figura do "intelectual orgânico", num sentido mais vasto que o conceito de A. Gramsci. Neste último se condensam aspectos essenciais das figuras anteriores, mas também surgem novas ambições relacionadas com formas de identificação projectiva com colectividades e com uma consciência histórica mais aguda sobre a sua vocação $0^{44}$.

$\mathrm{Na}$ época da II Guerra Mundial, retomando a dicotomia antiga do teórico e do prático a descrição de J. Benda da crise de "les clercs" revela como o estatuto dos intelectuais se relacionava cada vez mais com a faculdade de "fazer crer", como esta possuía nas "massas" ou na Nação os seus destinatários e como se apoiava numa visão passional do todo, da "ordem" ou da necessidade do devir histórico de forma a obter a mobilização

42 P. B. Shelley, A Philosophical View of Reform, London, New York, 1920, especialmente p. 30.

${ }^{43}$ M. Winock, Le Siècle des Intellectuels, o. c., p. 86 e ss.

${ }^{44} \mathrm{Cf}$. o retrato histórico sobre os intelectuais franceses "militantes" da causa soviética e as suas desventuras: Idem, Ibid., pp. 312-322. 
permanente ${ }^{45}$. Para o autor, esta nova função moderna, nacionalista e antidemocrática do "clero" opõe-se à auto-compreensão antiga, grega, segundo a qual o intelectual se dedicava a afazeres contemplativos, à "theoria" assim como à glorificação da "pessoa" e da liberdade.

Nos fenómenos de identificação projectiva, em que mergulha o intelectual orgânico, vamos encontrar o imaginário e o discorrer segundo imagens, ambos aspectos típicos do intelectual nacionalista ou do intelectual da vanguarda proletária, mas que conservam aquela forma da idealidade da sua anterior relação do educador para com os soberanos. $\mathrm{O}$ desejo do educador não foi o de se substituir ao soberano, mas o de poder julgar, com alguma margem de certeza, que havia criado neste último uma concretização do seu saber. Este desejo vai ser mimado pelo chamado "intelectual orgânico", esse fabricador de imagens políticas, não já em relação ao soberano mas em relação às massas e à História.

Tudo isto decorre integralmente do imaginário, mas de um imaginário que se coloca na posição de observar a acção política mediante o que os elementos simbólicos da linguagem, da comunicação escrita e da propaganda assegurarem.

Como formação característica da existência fantasmática, das formas projectadas na ausência dos originais, mas na modalidade da abreviatura e da fixação das relações internas de anteriores figuras vivas, o imaginário social e político deixou marcas profundas na arte moderna e contemporânea, dando testemunho de uma proximidade entre o desejo da soberania, uma visão sublime da História e a verdade. A fixação fantasmática é aquela que assegura o acoplamento entre as formas da consciência e as formas sociais da comunicação por gerar alguma coesão provisória entre umas e outras na modalidade das crenças e na coerência estética da visão do todo.

As imagens politicamente decisivas são figuras da embraiagem de esquemas da acção e da consciência nos mecanismos sociais do encadeamento das comunicações: mediante imagens comunicam-se concepções e gera-se comunicação mediante imagens.

$\mathrm{Na}$ imagem, cuja animação é toda interior, vem dela mesma e não daqueles a quem se destina, está figurada uma totalidade sem observadores, um estado do mundo dissociado de um intérprete, mas que se impõe como um dado sólido, inquestionável, ao homem comum. Entendo, portanto, por imagem, uma réplica de um todo. Mediante imagens o intelectual orgânico, herdeiro do preceptor e do publicista agitador, pode ter novas ambições: ele será, para o novo mundo, um produtor de imagens da necessidade histórica e do ser da sua comunidade.

45 J. Benda, La Trahison des Clercs, Paris (1927), reed. 2003. 
Uma imagem envolve a conservação das relações internas de um todo concebido. Pensar por imagens significa articular essas figuras do todo e deixar discorrer os sucessivos estados do mundo que nelas se vão deslindar. Neste aspecto, há uma ligação entre a actividade que consiste em formar imagens e a outra actividade que indica o que é ou como deve ser a ordem do mundo. Na medida em que o todo da imagem nos dá uma configuração viva é desta última que importa partir para mostrar uma regularidade, estabelecer uma regra ou comandar acções humanas. Neste sentido, temos de afirmar que todo o político precisa de imagens. É partindo deste sentido do conceito de imagem que podemos afirmar que o intelectual moderno, sobretudo o intelectual orgânico, foi um criador de imagens. Dele nunca se esperou verdadeiramente a "moral da história", mas o quadro do mundo, a sua figura viva, mas de tal modo que nela se não contivesse o observador implicado, como se tratasse de uma directa emanação das coisas. É precisamente também nestes termos que J. Benda, apoiado num artigo de H. Lefèvre de 1933 e em textos de G. Cogniot e R. Garaudy, avaliava, na segunda edição do seu La Trahison des Clercs, a imagem do mundo e da história do "materialismo dialéctico" que, contra a opinião destes seus adeptos, ele considerava contrária à tradição do racionalismo francês e oposta à razão, pois correspondia a uma vontade de "coincidir com a evolução do mundo" e a uma "união mística com o devir histórico"46.

$\mathrm{O}$ nexo entre o intelectual orgânico e as imagens pode ser analisado tendo em conta cinco vertentes mais centrais.

1. As imagens constituem o resultado de uma construção da ordem como configuração viva concebida e, nisso, elas são o fruto de actividades intelectuais e do pensamento.

2. As imagens confundem-se com a própria ordem enquanto ordem concebida, pois elas realizam a função da fixação do sentido.

3. Seguir um rumo significa politicamente seguir uma imagem no que ela assegura da configuração viva do todo na sua fixação do sentido.

4. As imagens ligam de novo os elementos das configurações vivas que se separaram em virtude de algum rompimento da unidade primitiva e, neste aspecto, o uso das imagens permite estabelecer uma associação entre o uso político, o estético e o uso religioso das imagens. A religação estabelece a totalidade.

46 Idem, Ibid., p. 34, nota 2. 
5. Pelas imagens se pode desenvolver um combate tanto mais ateado quanto é por imagens que os homens definem os destinos colectivos. Em parte, a diferença de posições políticas supõe a demarcação imaginária de mundos e a possibilidade de identificar símbolos de imagens novamente por imagens.

Em épocas históricas nas quais a luta política predomina e em que, por meio dela, a própria sociedade se observa como uma massa pilotada, as imagens encontram-se no seu esplendor. São elas os elementos catalíticos do movimento. É também nestes períodos que os usos políticos das imagens transgridem o plano propriamente político para adquirirem uma significação quase religiosa e seguramente um sentido estético. A relação das massas com o mundo das imagens que representam o sentido da História, a dura necessidade do tempo, foi contudo uma relação expressiva não da beleza mas do sublime.

$\mathrm{Na}$ sua expressão temporal isto significa que mediante imagens podemos conceber o fim do mundo ou o início absoluto. As extremidades do tempo encontram-se, pois, ligadas por imagens. A ligação das extremidades do tempo é especialmente poderosa nas utopias de massa. Neste caso, as imagens são pautas do movimento da História assim como designações do fim do movimento. Como quadros vivos, as imagens mais extremas das utopias de massas retratam o fim de todas as coisas. A propósito, lembremos a clarividência com que J. Benda associou o culto nacionalista da ordem com a representação da violência e da guerra. Estas representações extremas não nos dão a réplica do fim apocalíptico apenas como expressão-quadro, mas como figuras activas da negação e da catástrofe ${ }^{47}$.

A actividade política que se afastou das representações ideológicas do passado está também em parte distanciada do pensamento por imagens do todo. A actividade do intelectual orgânico que havia consistido na formação e divulgação das imagens do mundo histórico transformou-se muito profundamente na época contemporânea. O conceber segundo imagens e a actividade do intelectual orgânico deixou entretanto de estar no centro da actividade política, embora o poder das imagens não se tenha esgotado ou desaparecido.

Depois da época do fim dos intelectuais orgânicos, o que a sociedade moderna hoje dá a perceber é a inexistência de qualquer laço entre o antigo lugar do soberano, a história universal e a função da criação de imagens.

${ }^{47}$ Sobre este tópico pode consultar-se o trabalho profusamente ilustrado de S. Buck-Morss, Dreamworld and Catastrophe. The passing of mass utopia in East and West, Cambridge (Mass.), London, 2002. 
É por isso que o grande deslocamento da nossa época não é apenas de ordem estrutural, mas traduz-se de um modo especial no plano do imaginário, do imaginário político, especificamente.

Os tipos contemporâneos do intelectual sumariamente se decomporiam em dois modelos: o intelectual como conselheiro (o expert) e o intelectual como mediador (o opinion-maker). O primeiro define-se pela relação forçosa com o sistema político e com a diferença entre governo e oposição. O segundo tipo já implica a relação com aquilo que nas sociedades modernas assegura a visibilidade do político, ou seja, a imprensa, os "mass-media".

A situação dos intelectuais na época contemporânea está articulada com o grau de profissionalização da função política por um lado, com a autonomização crescente do sistema da ciência e com a institucionalização de uma esfera pública que requer uma sustentação em opiniões legitimadoras que, mediante a profissionalização dos actores dos "mass-media", emerge na figura do "especialista" ou na do "opinion maker" generalista. Ambos os tipos acabados de referir resultam da evolução de duas instituições da sociedade moderna: a universidade e a imprensa.

A universidade serviu de instituição formadora dos intelectuais mas, em vários países europeus e na América do Norte, também desempenhou a função de distanciamento em relação à militância política dos seus membros, criando e mantendo a autonomia do sistema da ciência em relação ao sistema politico.

Por seu lado, nas condições actuais, os "mass-media" não se resumem a folhas literárias de discussão, a órgãos de combate ou a veículos das grandes imagens dos intelectuais. Não só a informação é um valor em si mesmo mas mesmo o que não tem um valor de informação imediato deve subordinar-se à "agenda" e o resto é entretenimento.

A crise da Filosofia Política do nosso tempo deixa-se ler substancialmente na crise de imagens políticas, na pobreza do nosso imaginário quando comparado com os grandes frescos dos dois grandes totalitarismos do século passado. Ela é, também, atravessada pela crise dos intelectuais. Todavia, as tarefas da Filosofia Política não se eliminam com a destruição do laço orgânico entre os intelectuais, as grandes imagens da totalidade e o poder político.

Aquilo que surge deslocado do seu anterior berço é o grau, a intensidade do uso político da imaginação e a conexão entre uso político da imaginação e estratégia política.

Os dois temas do Homem e da Polis, de cuja associação nascia para Leo Strauss o núcleo definidor da Filosofia Política, representam, sobretudo, os dois conceitos em que a tradição filosófica organizou, num discurso, o nexo entre a impossibilidade de manter com a posição do soberano uma relação de igualdade e a descrição dessa impossibilidade. 


\section{III - As Tarefas da Filosofia Política na sociedade moderna}

$\mathrm{Na}$ sociedade moderna funcionalmente diferenciada a tarefa do intelectual e do filósofo da política não pode já ser a de reforçar a ideia de uma continuidade entre consciência, acção e comunicação mediante a representação de um mundo objectivo, regulado pela virtude ou pelas imagens que vão pautando o sentido da evolução da História. Ao "novo clero" não se pedem mitos ou novas imagens da ordem do mundo, mas a identificação das conexões operatórias que se mantêm quando observamos o mundo como "contendo" ou "reflectindo" esta ou aquela regularidade. Exige-se do filósofo da política observações de segundo grau credíveis, observação de observadores, capacidade para revelar nas imagens da "ordem" os seus criadores e as suas estratégias. Nisto se cumpre a pendularidade descritivo-normativa do seu saber: ela não pode reduzir-se à orientação prática da vida dos homens sem se tornar em uma preceptiva sem recuo possível em relação às suas consequências na construção de determinadas formas de mundo; não pode, por outro lado, ser apenas discurso teórico, descrição, ou saber histórico, pois com isso perderia aspectos essenciais da própria inteligibilidade, uma vez que tornar inteligível o mundo implica torná-lo acessível à intervenção dos homens.

1. Na relação com a história dos intelectuais está a efectivação de uma parte considerável dos cinco enlaces reflexivos da Filosofia Política na sociedade moderna, mas nas condições contemporâneas essa história tem de ser observada por um tipo de observador que já não se identifica com o criador de imagens porque o seu papel não é já o de dar a ver a ordem como se ela não tivesse sido gerada numa observação particular, mas o que dele se espera é o acto de restituir à imagem o valor de um elemento em uma cadeia de operações, acto de restituição esse em que forçosamente vão ficar confirmados a observação e o observador em virtude dos quais se esboçou aquele quadro do mundo.

2. Adicionalmente, na medida em que devem compreender como, nas condições da sociedade moderna, a consciência e a vontade não possuem nem resultam da mesma história da selecção que a comunicação e os sistemas sociais baseados na comunicação, os filósofos da política estarão preparados para mostrar em redor das imagens com que se preenche o vazio do conjunto dos dois conjuntos o "mal estar da civilização", a impossível sincronia entre o tempo da comunicação e o tempo da consciência, a sua irreali- 
zável reciprocidade e como isso tem consequências no discurso moral. Os filósofos da política verão nos grandes mitos políticos deste e de outros séculos imagens de luto e de dor, do sofrimento simbólico em que assenta a civilização. Neste sentido, a Filosofia Política pode tornar-se, com proveito, em teoria da cultura, mais concretamente, em teoria das imagens culturais. Só o será, porém, se entender em que lhe pode ser útil a teoria dos sistemas sociais na clarificação da diferença de temporalidade entre sistemas psíquicos e sistemas sociais. Neste sentido, a Filosofia Política terá de se tornar num saber muito mais complexo e subtil do que aquele que lhe estava prometido na dupla forma platónica do "conselho a tiranos" ou da "instrução para o vulgo", que é definitivamente incompatível com a modernidade e, sobretudo, com a crescente capacidade dos públicos para lançarem o opróbrio sobre os condutores das multidões.

3. A argumentação moral e a discussão pública constituem, sem dúvida, aspectos da relação entre o sistema político democrático e o "espaço público". A crise dos intelectuais e o aumento de complexidade interna da sociedade moderna não vão fazer desaparecer a argumentação moral. Mas a Filosofia Política deve estar alerta para os efeitos retóricos de argumentos que não se submetem a escrutínio. Se ela deve ser crítica, no sentido não infantil do termo, é justamente contra o excesso de facilidade com que se julga poder retirar um resultado interessante em Filosofia de um argumento bem sucedido na prática política ou no discurso legitimador ou vice-versa. É também nesta acepção que sustento que aquilo que vier a resultar historicamente desta disciplina deve poder situar-se entre o discurso universitário e a argumentação pública, pois só neste enclave é possível manter equilíbrios entre ciência e discurso normativo. Deste modo, evita cair-se numa defesa implícita de semânticas redutivas a que muitas vezes assistimos quando nos confrontamos com a preferência de alguns filósofos pelo recurso à argumentação moral como um fundamento construtivo exclusivo em Filosofia Política. É por isto que considero que a ideia da "racionalidade prática" é hoje insuficiente para dar conta das tarefas da Filosofia Política quer se entenda por este rótulo o modelo da Política clássica da tradição grega ou a sua modalidade kantiana. 